Dette positive billede blev hurtigt vendt på hovedet, $\mathrm{fx}$ hos Marx, som i spindemaskinen så bekræftelsen på, at 'kapitalen, når den tager videnskaben $\mathrm{i}$ brug til sine formål, altid tvinger arbejdets rebelske hånd til at føje sig'. Et billede, vi alle kender fra Chaplins ikke mindre kritiske Modern Times. På samme tid følger en heftig kritik af fabrikken, der bliver et billede på verdens hæslighed. 'Dark Satanic Mills', som det hedder hos William Blake,'et monster af jern, en Molok med et hjerte af stål, en kæft så stor som graven, med tænder af stål og klør af messing'.

Allermest interessant bliver bogen dog når den forholder sig til det klassiske billede af fabrikken, det være sig Chaplins imaginære eller Fords virkelige. Det fremgår tydeligt, at Ford som teknolog og producent ikke længere er et retvisende billede af den typiske fabrik. Som afslutning på bogen reflekterer forfatterne grundigt over fabrikkens eventuelle forsvinden. Fabrikken som vi kender den er under pres, fordi det at 'fabrikere' er under pres. Med den stigende dematerialisering af produkter $i$ et måske kommende videnssamfund er det ikke længere så let at forstå, hvad der produceres. I de nye netværksfabrikker er information ikke blot en ny produktdimension, det er den nye indsatsfaktor $i$ det hele taget. Er fabrikken ved at lukke ned, ved at blive til et arkiv der ikke længere hører samtiden til, men snarere fortiden? Lever vi stadig i en fabriksverden?
Forfatterne slutter med et rungende ja, men påpeger, at fabrikken i dag er blevet en flygtig størrelse, som ikke lader sig begrænse af, hvad vi hidtil har kendt som fabrikken. Et er sikkert og vist: Fabrikken vil vedblive at være et af de mest interessante og dominerende kulturprodukter, mennesket har skabt.

Frank Beck Lassen

\section{Heidegger og humanismen}

Martin Heidegger: Et brev om humanismen. Informations Forlag 2004, 88 sider, kr. 128,-

En af de mest berømte tekster i det 20 århundredes filosofi er egentlig et brev, som Martin Heidegger forfattede med henblik på at besvare den franske tænker Jean Beaufrets venlige henvendelse, der indeholdt en række spørgsmål. Hvoraf de væsentligste lyder: (1) Hvordan kan ordet 'humanisme' gives en mening påny?, (2) Hvordan lader forholdet imellem ontologien og en mulig etik sig præcisere?, (3) Hvordan reddes det eventyrlige, som enhver udforskning rummer et element af, uden at filosofien gøres til en ren og skær eventyrer? Som de to oversættere, Søren Gosvig Olesen og Karin Wolgast, gør opmærksom på $i$ den fremragende indledning til den ligeså fremragende oversættelse af 'Et brev om 'humanismen', så gentager Heidegger i brevet Beaufrets spørgsmål på sin egen karakteri- 
stiske facon, hvorefter spørgsmålene kommer til at indgå i en omfattende, kritisk betænkning af den vestlige kultur som sådan. Heideggers humanisme-brev er intet mindre end det veritable forsøg på at gentænke de væsentlige filosofiske kategorier fra det antikke Grækenland, over den europæiske oplysningstænkning og religionens død, til nutidens teknologiske tidsalder med henblik på at give plads til en anden forståelse af menneskets væsen.

Heidegger ønsker således på den ene side at imødekomme Beaufrets appel om at give humanismen en mening påny, men da denne mening på den anden side er 'ældre' eller mere oprindelig end humanismen selv, så kan besvarelsen ifølge Heidegger ikke tage form af en traditionel aktualisering af humanismens kategoriske forståelse af menneskets væsen. Af den grund er Heidegger tilbøjelig til helt at opgive termen 'humanisme', hvis metafysiske fundament - mennesket som samfundsvæsen, naturvæsen, fornuftsvæsen - til stadighed tilslører det, der egentlig er ejendommeligt for mennesket, og som hverken lader sig fundere eller virkeliggøre i det værendes principper, nemlig at det er til som mulighed. Hvis denne indsigt hos Heidegger ofte er blevet udlagt inden for horisonten af eksistentialismen, så gør forfatteren til 'Et brev om 'humanismen" et helhjertet forsøg på at distancere sig fra denne udlægning og for at føre sin egen tænkning og samtidig dermed forståelsen af menne- skevæsenet tilbage til deres egentlige element: Heidegger genudlægger det tyske 'Möglichkeit' over verbet 'mögen', der i forste omgang gives den betydning at elske som dét at tage sig af noget eller nogen, om hvilket det derefter hævdes, at dets mere oprindelige betydning er at skænke noget dets væsen. At mennesket eksisterer i kraft af at være mulighed, betyder ifølge Heidegger således ikke at det væsentlige $\mathrm{i}$ tilværelsen bestemmes af mennesket; tværtimod skænkes mennesket det, som væsentligt set er det ejendommeligt. En skænken, der sker i det øjeblik, hvor mennesket eksisterer som mulighed eller væren til på en måde, som først og fremmest er givet. Det er Heideggers tese i 'Et brev om 'humanismen', at denne 'laden væren være' kun åbner sig som en mulighed i tænkningen, som mennesket ikke magter eller er i stand til at udføre, men som det tilhører i kraft af at opholde sig ved eller rettere at bo i sproget. Nogle af de første ord i brevet lyder: 'Sproget er værens hus. I dets bolig bor mennesket', hvilket peger på det forhold, at det er væren, der igennem sproget og tænkningen skænker mennesket det væsentligste, nemlig dets eget, dets sted, dets stand.

Heidegger varierer denne indfaldsvinkel til humanismen og humanitas på stadig nye måder, hvis fortrin det er aldrig at forfalde til blot at gengive de overleverede, filosofiske kategorier. Disse kategoriers meta-fysiske begrebsindhold bliver deri-mod 
hele tiden tænkt igennem påny $\mathrm{i}$ det kritiske øjemed at udlægge den værensforstålse, som er dem iboende. 'Et brev om 'humanismen" rummer således også historien om det forfald, som er blevet en integreret del af den vestlige kultur og humanisme med dens pragmatiske og teknologiske tilgang til alt værende. I en vis forstand øver Heidegger ingen kritik af, at tingene forholder sig sådan, men han fremlæser den tingslige værensforståelse, som slår sig ned i forståelsen af mennesket og dets omgivelser. Om Heidegger lykkes med sine 'lyttende' udlægninger, og om de ikke fra først til sidst er båret af en kærlighed til tingene, sådan som de viser sig $\mathrm{i}$ deres 'uforbehandlede' væren (så der altså bliver en tale om en kritik, der ganske vist ikke kommer fra Heideggers hoved, men fra hans hjerte), det forbliver et spørgsmål, som igen afføder et nyt: hvor bliver humanismen af, hvis ikke menneskene ad fælles vej, igennem tale og handling kan give hinanden det væsentligste $\mathrm{i}$ tilværelsen, men skal skænkes dette af en upersonlig skæbnemagt? Det er disse spørgsmål Heideggers arvtagere i henholdsvis Tyskland (Gadamer, Arendt, Habermas), Frankrig (Lévinas, Derrida, Nancy) og Italien (Pereyson, Vattimo, Agamben) igennem de sidste halvtreds år har genoptaget, hvilket aflægger et yderst troværdige vidnesbyrd om humanisme-brevets og overhovedet Heideggers kolossale indflydelse på det 20. århundredes filosofi. 'Et brev om 'humanismen" er adresseret til alle fremtidige forsøg på at gentænke menneskets væsen, dets menneskelighed og værdighed, hvilket tænkningen, forsåvidt den fortsat vil være tænkning, aldrig vil holde op med at genoptage.

Jonas Holst Sorensen

\section{Rencessancens religiost betingede videnskab.}

Morten Fink-Jensen. Fornuften under troens lydighed. Naturfilosofi, medicin og teologi i Danmark 1536 -1636, Museum Tusculanum, Kobenhavn, 2004, 418 sider, kr. 325,-

Morten Fink-Jensen (MFJ) har begået et stykke lærd, kildenært og velskrevet idéhistorie, der beskæftiger sig med en periode i dansk idéhistorie, som ikke før er behandlet samlet. Fornuften under troens lydighed, udgivet i 2004, er en revideret version af MFJs ph.d.-afhandling fra Institut for Historie ved Københavns Universitet.

Tiden efter reformationen beskrives traditionelt ud fra to perspektiver: På den ene side som perioden for de revolutionære videnskabelige opdagelser, grundlæggelsen af nye metoder og teorier inden for naturvidenskaben. På den anden side som en tid behersket af åndeligt armod, da sammenbindingen af statens og kirkens interesser førte til stigende religiøs og social kontrol. De to perspektiver fremmaner tilsammen et billede af konflikt imellem tro og 